\title{
Holocene evolution of the North Atlantic subsurface transport
}

\author{
Janne Repschläger $^{1, a}$, Dieter Garbe-Schönberg ${ }^{1}$, Mara Weinelt ${ }^{2}$, and Ralph Schneider ${ }^{1}$ \\ ${ }^{1}$ Institute of Geosciences, Kiel University, 24118 Kiel, Germany \\ ${ }^{2}$ Institute of Prehistoric and Protohistoric Archaeology, Kiel University, 24118 Kiel, Germany \\ anow at: Climate Geochemistry Department, Max Planck Institute for Chemistry, 55128 Mainz, Germany
}

Correspondence to: Janne Repschläger (j.repschlaeger@mpic.de)

Received: 9 November 2016 - Discussion started: 21 November 2016

Revised: 1 March 2017 - Accepted: 1 March 2017 - Published: 10 April 2017

\begin{abstract}
Previous studies suggested that short-term freshening events in the subpolar gyre can be counterbalanced by advection of saline waters from the subtropical gyre and thus stabilize the Atlantic Meridional Overturning Circulation (AMOC). However, little is known about the inter-gyre transport pathways. Here, we infer changes in surface and subsurface transport between the subtropical and polar North Atlantic during the last 11000 years, by combining new temperature and salinity reconstructions obtained from combined $\delta^{18} \mathrm{O}$ and $\mathrm{Mg} / \mathrm{Ca}$ measurements on surface and subsurface dwelling foraminifera with published foraminiferal abundance data from the subtropical North Atlantic, and with salinity and temperature data from the tropical and subpolar North Atlantic. This compilation implies an overall stable subtropical warm surface water transport since $10 \mathrm{kaBP}$. In contrast, subsurface warm water transport started at about $8 \mathrm{ka}$ but still with subsurface heat storage in the subtropical gyre. The full strength of intergyre exchange was probably reached only after the onset of northward transport of warm saline subsurface waters at about $7 \mathrm{ka} \mathrm{BP}$, associated with the onset of the modern AMOC mode. A critical evaluation of different potential forcing mechanisms leads to the assumption that freshwater supply from the Laurentide Ice Sheet was the main control on subtropical to subpolar ocean transport at surface and subsurface levels.
\end{abstract}

\section{Introduction}

The Holocene, though often considered a generally stable warm climate mode, is characterized by distinct long-term climate trends, superimposed by strong oscillations on millennial to decadal timescales (e.g., Mayewski et al., 2004).
The long-term evolution is formally divided into the early Holocene (11.6 to $8.2 \mathrm{ka} \mathrm{BP})$, the mid-Holocene (8.2 to $4.3 \mathrm{ka} \mathrm{BP}$ ), and the late Holocene (4.3-0 ka BP) (Walker et al., 2012). This gradual change is caused by variations in the incoming solar radiation due to changes in Earth's orbit, expressed as insolation at $60^{\circ} \mathrm{N}$ in June. Northern hemispheric insolation changes are inferred to control strength and position of the global wind systems and to have caused the early Holocene thermal maximum observed in the high northern latitudes (e.g., Leduc et al., 2010; Moros et al., 2006). This warming induced the final melting of glacially extended ice sheets and released a significant amount of meltwater from the Laurentide Ice Sheet into the North Atlantic (e.g., Jennings et al., 2015).

Shorter periodic climatic cycles, with average duration of about 1500 years, are observed in many Holocene climate records, and are superimposed on the long-term trend. The causes of these cycles are controversially discussed, with hypotheses ranging from meltwater pulses induced by variations in solar irradiance to internal ocean-ice-atmosphere feedback mechanisms or volcanism (e.g., Andrews and Giraudeau, 2003; Bond et al., 2001; Campbell et al., 1998; Schulz et al., 2004; Viau et al., 2006; Wanner, 2008). Due to the wide range of feedback mechanisms, involving northern hemispheric oceanic and atmospheric circulation, climate patterns with strong local differences are observed for the Holocene. Therefore, identification and understanding of the importance of the different driving forces and stabilizing mechanisms for the Holocene climate remains challenging. It is assumed that the stabilization is related to a strong Atlantic Meridional Overturning Circulation (AMOC), driven by deep-water formation in the Nordic seas and the Labrador Sea, and fueled by the northward transport of warm saline 
waters. In this scenario, the main stabilization occurred via the formation of the Labrador Sea Water (LSW), which was probably well established at about $7 \mathrm{kaBP}$ (Hoogakker et al., 2011; Kissel et al., 2013; Solignac et al., 2004; Thornalley et al., 2013). A stable LSW formation relies on the interaction between warm water transport in the clockwisecirculating subtropical gyre (STG) and the subpolar gyre (SPG), circulating counterclockwise in the Irminger Basin and the Labrador Sea (Thornalley et al., 2009). Antiphase heat and salt storage within the STG during times when SPG freshens (Cléroux et al., 2012; Thornalley et al., 2009) and the subsequent advection of the warm saline water into the SPG leads to a strengthening of the deepwater formation by convection within the SPG (e.g., Born and Stocker, 2014).

The warm water transport into the subpolar North Atlantic and the Nordic seas via surface flow within the North Atlantic Current (NAC) is relatively well known from oceanographic studies (Sarafanov et al., 2012) and paleoceanographic reconstructions (e.g., Andersen et al., 2004; Came et al., 2007; Farmer et al., 2011; Giraudeau et al., 2010; Moros et al., 2004; Staines-Uréas et al., 2013). However, investigation of surface and subsurface pathways of the warm water masses from the tropical into the subpolar North Atlantic is limited to a few studies thus far, as is true also for the different branches of the warm water transport either into the Azores Current (AC) or the Irminger Current (IC), the latter feeding into the Labrador Sea (Fig. 1).

Drifter and modeling studies of the modern ocean indicate a lack of warm surface water transport vis-à-vis a major warm water transport into the SPG via a subsurface $(>500 \mathrm{~m}$ ) pathway into the Irminger Sea (Brambilla and Talley, 2006; Foukal and Lozier, 2016; Lozier, 2012). In contrast, hydrographic data from ocean cross sections indicate a transport of warm saline water between 10 and $1000 \mathrm{~m}$ water depth into the Irminger Basin and Labrador Sea (Sarafanov et al., 2012; Våge et al., 2011), with a recirculation and mixing zone of NAC waters into the SPG in the northwest corner of the SPG (Mertens et al., 2014).

Most paleo-reconstructions focus on the surface water structure in the subpolar North Atlantic (Came et al., 2007; Farmer et al., 2011; Staines-Uréas et al., 2013) and neglect the probably-significant subsurface component of the transport. The two studies that investigated the interaction between the STG and SPG (Solignac et al., 2004; Thornalley et al., 2009) mainly address surface water pathways, while changes in the tropical origin of the water masses are not considered. Thus, a systematic investigation of the subsurface transport from the tropical into the subpolar North Atlantic and its potential impact on the stabilization of the Holocene AMOC mode is apparently missing. For that reason, the role of surface and subsurface warm water transport from the tropics into the subpolar North Atlantic on the evolution and stabilization of the Holocene climate mode is investigated and different forcing mechanisms are discussed here. This knowledge is pivotal to establish more robust scenarios for future $\mathrm{AMOC}$ changes under ongoing anthropogenic climate change leading to warming and potential freshening of the subpolar NA.

\section{Regional setting}

The warm water circulation in the North Atlantic is governed by the NAC, which transports warm saline water (e.g., Roessler et al., 2015) into the high northern latitudes. On its northward path, several warm water currents branch off the main pathway (Fig. 1). The most distinct ones are the $\mathrm{AC}$ and the IC. The eastward-flowing AC leaves the NAC between 30 and $40^{\circ} \mathrm{N}$ and forms the northern boundary of the STG. The latter rotates clockwise and recirculates warm water between 10 and $40^{\circ} \mathrm{N}$. The AC is associated with the Azores Front (AF), which is characterized by strong eddy activity and forms the boundary between cool transitional and warm oligotrophic subtropical waters. The formation and about $75 \%$ of volume transport of the AC are driven by the strength of Mediterranean outflow (Volkov and Fu, 2010), whereas $25 \%$ of the AC strength and the latitudinal position of the $\mathrm{AF}$ and $\mathrm{AC}$ west of $20^{\circ} \mathrm{W}$ are probably controlled by the position of the westerly wind belt (Volkov and Fu, 2011) with increasing or decreasing wind strength leading to a southward or northward displacement of the AF, respectively. South of Iceland at about $50^{\circ} \mathrm{N}$, the IC branches off the main northward path of the NAC. It flows in a northwestward direction following the bathymetry of the Irminger Basin. South of the Denmark Strait, the IC returns southward, following the coast of Greenland into the Labrador Sea (Spall and Pickart, 2003). It thereby feeds warm saline waters into the counterclockwiserotating SPG and fuels deepwater convection in the Labrador Sea (Born and Stocker, 2014; Sarafanov et al., 2012; Våge et al., 2011).

\section{Methods}

For our study, we used core GEOFAR KF16 taken at $38^{\circ} \mathrm{N}$ south of the Azores Islands from $3060 \mathrm{~m}$ water depth at the Mid-Atlantic Ridge. The age model for this core was published in Schwab et al. (2012). The position of core GEOFAR $\mathrm{KF} 16\left(38^{\circ} \mathrm{N}, 31.13^{\circ} \mathrm{W}\right)$ in the vicinity of the AF is ideal to trace changes in STG position and associated varying influence of subtropical and temperate waters (Repschläger et al., 2015). Results are compared to published data from the western subtropical (Bahr et al., 2013; Cléroux et al., 2012) and subpolar North Atlantic (Thornalley et al., 2009) along the warm water route.

We combine published $\delta^{18} \mathrm{O}$ data of planktonic surface and subsurface dwelling foraminifera G. ruber w. (Schwab et al., 2012) and G. truncatulinoides (Repschläger et al., 2015) with new $\mathrm{Mg} / \mathrm{Ca}$ records from the same species. All measurements were conducted on samples of the size fraction $315-400 \mu \mathrm{m}$ on monospecific samples of 10-25 specimens of 


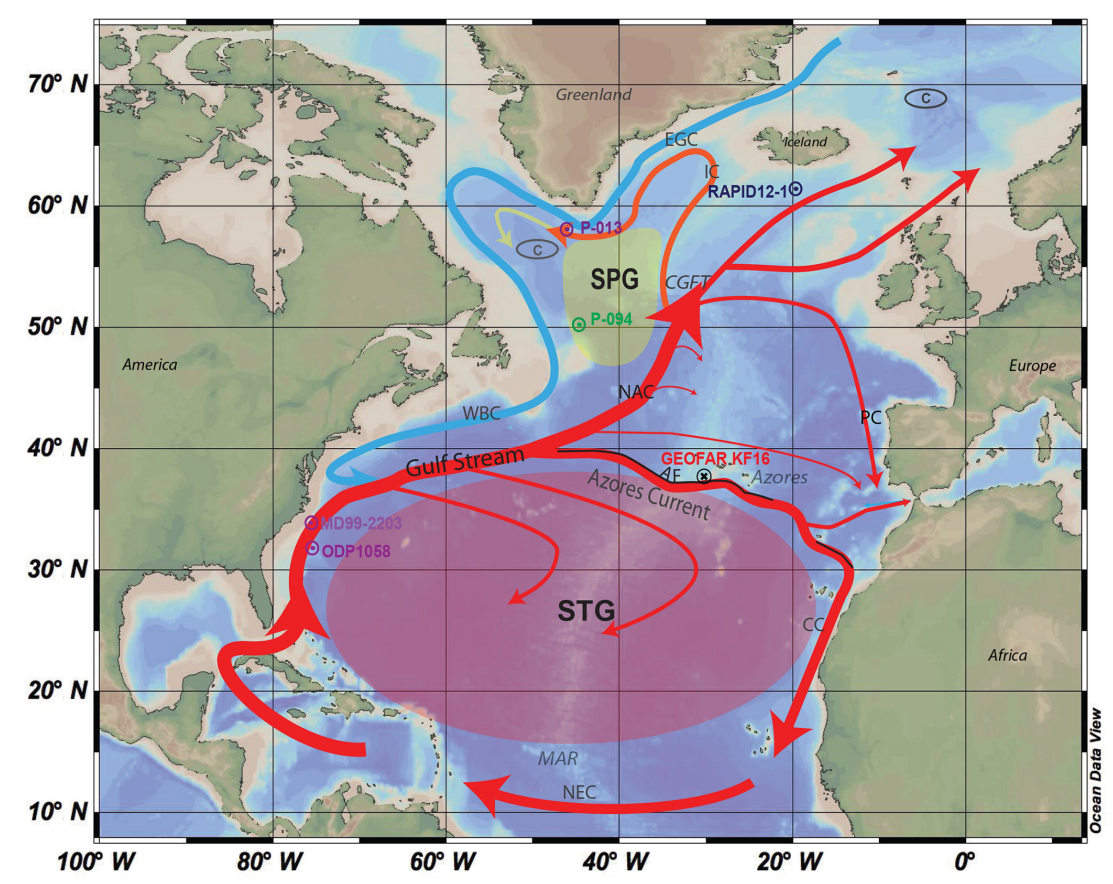

Figure 1. Modern surface water hydrography of the North Atlantic currents are modified from Schott et al. (2004) and Lherminier et al. (2010); basic maps stem from ocean data view (Schlitzer, 2012). Warm surface currents are shown by red arrows. The black line indicates the position of the Azores Front (abbreviations are AC, Azores Current; AF, Azores Front; FC, Florida Current; IC, Irminger Current; NAC, North Atlantic Current; NEC, North Equatorial Current; STG, subtropical gyre; SPG, subpolar gyre; PC, Portugal Current; TW, transitional water; WBC, western boundary current). (C) symbols indicate the position of deepwater convection sites, and the Mid-Atlantic Ridge is marked with MAR.

G. ruber w. and 15 specimens of mixed left- and right-coiling G. truncatulinoides. Stable isotope analyses were carried out at the Leibniz Laboratory for Radiometric Dating and Stable Isotope Research at Kiel University. For analyses, a Finnigan MAT 253 mass spectrometer coupled with a Kiel I carbon preparation device was used and results were calibrated to the Vienna Pee Dee Belemnite (VPDB) scale. The $2 \sigma$ standard deviation (SD) obtained from 10 replicates of downcore samples was $\pm 0.11 \%$ o for $G$. ruber w. and $0.12 \%$ o for G. truncatulinoides. $\mathrm{Mg} / \mathrm{Ca}$ analyses followed the cleaning procedure of Martin and Lea (2002), using reductive and oxidative cleaning. Measurements were carried out with a simultaneous inductively coupled plasma optical emission spectrometry (ICP-OES) instrument with radial plasma observation. Potential shell contamination or coatings by authigenic minerals were monitored using additional $\mathrm{Fe}, \mathrm{Al}$, and $\mathrm{Mn}$ measurements. Analytical $2 \sigma$ SD was $\pm 0.20 \mathrm{mmol} \mathrm{mol}^{-1}$ $\mathrm{Mg} / \mathrm{Ca}$ for G. ruber w. and $\pm 0.14 \mathrm{mmol} \mathrm{mol}^{-1} \mathrm{Mg} / \mathrm{Ca}$ for G. truncatulinoides. To convert $\mathrm{Mg} / \mathrm{Ca}$ values into water temperature estimates, we used the principal equation format $\mathrm{Mg} / \mathrm{Ca}=b \exp (a \cdot T)$ with species-specific variables $a=0.76$ and $b=0.07$ for $G$. ruber w. and $a=0.78$ and $b=0.04$ for $G$. truncatulinoides proposed for the equation for mixed subsurface dwellers (Cléroux et al., 2008). The summed analytical and calibration $2 \sigma$ SD is $\pm 1^{\circ} \mathrm{C}$ for $G$. ruber w. and $\pm 2{ }^{\circ} \mathrm{C}$ for $G$. truncatulinoides. The calibrated
$\mathrm{Mg} / \mathrm{Ca}$ temperature estimates for both species in core top samples match well with modern surface and subsurface (200 m depth) temperatures at the Azores coring site. Seasonal temperature effects on the foraminiferal $\mathrm{Mg} / \mathrm{Ca}$ signal are assumed to play a subordinate role at our coring site (Repschläger et al., 2015). In addition, we assume that the subsurface temperature signal of $G$. truncatulinoides is predominantly determined by the conditions at the AF and not by the migration of $G$. truncatulinoides to shallower, warmer water depths or by thermocline shoaling (see Supplement and Repschläger et al., 2015).

Changes in salinity are reconstructed following the procedure described in Repschläger et al. (2015). The temperature effect, estimated from the $\mathrm{Mg} / \mathrm{Ca}$, was removed from the foraminiferal $\delta^{18} \mathrm{O}_{\text {carbonate }}$ using the general equation of Shackleton (1974) for both G. ruber w. and G. truncatulinoides in order to be consistent with the datasets used for comparison. A correction for VPDB to standard mean ocean water (SMOW) was included. Resulting seawater $\delta^{18} \mathrm{O}_{\mathrm{w}}$ values are discussed in the following. For estimation of $\delta^{18} \mathrm{O}_{\mathrm{w}}$ uncertainties, we followed the approach of Cléroux et al. (2012) and used their Eq. (S8)

$$
\sigma_{\delta^{18} \mathrm{O}_{\mathrm{sw}}}=\sqrt{\left(\sigma_{\delta^{18} \mathrm{O}_{\mathrm{for} \mathrm{am}}}\right)^{2}+\sigma_{\mathrm{Temp}}^{2}(0.23)^{2}}
$$


leading to a calculated $2 \sigma$ SD of $\pm 0.35 \%$ ofor $G$. ruber w. and $\pm 0.68 \%$ o for $G$. truncatulinoides. For interpretation of the temperature and $\delta^{18} \mathrm{O}_{\mathrm{w}}$ values, we only used 3-point average time series to investigate longer-term trends in the datasets. The $\delta^{18} \mathrm{O}_{\mathrm{w}}$ records were corrected for ice volume, using the relative sea level composite curve of Austermann et al. (2013), assuming a $1.2 \%$ glacial-interglacial change in marine $\delta^{18} \mathrm{O}$. The corrected data are expressed as $\delta^{18} \mathrm{O}_{\mathrm{w} \text {-ivc }}$ values throughout the text.

Changes in the AF front were reconstructed using the relative abundance of G. ruber w. published by Weinelt et al. (2015). These abundance counts have a $2 \sigma$ SD of $\pm 2.5 \%$. G. ruber w. is most abundant within the STG (Ottens, 1991; Schiebel et al., 2002; Storz et al., 2009), low abundances therefore indicate a southward movement and high abundances indicate a northward movement of the AF relative to the coring site. Because the position of the AF is related to changes in the westerly wind belt, the abundances of $G$. ruber $\mathrm{w}$. can be used as a tracer of the position of westerlies (see also argumentation in Repschläger et al., 2015).

\section{Results}

Surface and subsurface $\delta^{18} \mathrm{O}$ records (Fig. 2a) show a parallel trend over the Holocene, with a $0.5 \%$ o decrease from 0.2 and $1.5 \%$ at $11 \mathrm{ka} \mathrm{BP}$ to -0.3 and $0.9 \%$ at $8 \mathrm{ka} \mathrm{BP}$. After $6 \mathrm{kaBP}$, both records stabilize with minor fluctuations of $0.2 \%$ around an average of 0.3 and $1 \%$. Additionally, both records show a major positive $\delta^{18} \mathrm{O}$ excursion of $0.7 \%$ between 7 and $6 \mathrm{ka} \mathrm{BP}$ that is probably related to a discontinuity within the core.

The sea surface temperature (SST) record of G. ruber w. (Fig. 2b) is relatively stable over the entire Holocene, fluctuating between 17.5 and $20^{\circ} \mathrm{C}$. In contrast, subsurface temperatures $\left(T_{\text {sub }}\right)$ show an increase from low temperatures around $12.5^{\circ} \mathrm{C}$ at $11 \mathrm{kaBP}$ to about $17^{\circ} \mathrm{C}$ between 11 and $8 \mathrm{kaBP}$. Over the last $7 \mathrm{ky} \mathrm{BP}, T_{\text {sub }}$ fluctuate by $2.5^{\circ} \mathrm{C}$ around an average value of $16^{\circ} \mathrm{C}$ and are parallel to the surface water record with an average offset of $\sim 4^{\circ} \mathrm{C}$.

The $\delta^{18} \mathrm{O}_{\mathrm{w} \text {-ivc }}$ records of the surface and subsurface water (Fig. 2c) both show strong short-term variability of $0.5 \%$. The 5-point average values of both records, however, reveal an analogous evolution (Fig. 3). Both records are similar between 11 and $10.5 \mathrm{ka}$, with average values between 0.3 and $0.5 \%$. Between 10.5 and $10 \mathrm{kaBP}$, the records start to increase to values between 1.5 and $1.7 \%$ at $6 \mathrm{kaBP}$. After $6 \mathrm{kaBP}$ surface and subsurface $\delta^{18} \mathrm{O}_{\mathrm{w} \text {-ivc }}$ records separate, but only slightly exceeding the error of calculation.

Low abundances of $G$. ruber w. $<15 \%$ are found in sediments older than $9 \mathrm{kaBP}$. High abundances of G. ruber w. $(\sim 20 \%)$ are observed between 8 and 4 ka BP. Between 6 and $7 \mathrm{ka}$ BP a short excursion with a decrease in G. ruber w. abundances to as low as $10 \%$ coincide with an increase in the $\delta^{18} \mathrm{O}$ records and a decrease in $T_{\text {sub. This event is associated }}$ with a discontinuity in the sediment core. After $4 \mathrm{ka}$ BP the abundance of G. ruber w. decreases to $15 \%$.

\section{Discussion}

The AF is characterized by the depth of the $15^{\circ} \mathrm{C}$ isotherm (Gould, 1985) and is therefore not traceable in SST (Alves et al., 2002) but by distinct shifts in foraminiferal assemblages from subtropical to transitional and/or subpolar species (Ottens and Nederbragt, 1992; Schiebel et al., 2002) and thus also by abundances of G. ruber w. (Repschläger et al., 2015, and citations therein). Low abundances of G. ruber w. (7$15 \%$ ) (Fig. 2d) between 11 and $9.5 \mathrm{kaBP}$ indicate a southward displacement of the AF and correlate with low $T_{\text {sub }}$ and low subsurface $\delta^{18} \mathrm{O}_{\mathrm{w} \text {-ivc }}$. High abundances of G. ruber w. $(\sim 20 \%)$ between 8 and $4 \mathrm{ka} \mathrm{BP}$ indicate a northward movement of the AF, coeval to a warming of the subsurface waters and high $\delta^{18} \mathrm{O}_{\mathrm{w} \text {-ivc }}$ in G. truncatulinoides. After $4 \mathrm{kaBP}$, the abundances of $G$. ruber $w$. decrease to about $15 \%$, indicating a southern position of the AF. This decrease initially coincides with a slight decrease in surface and subsurface $\delta^{18} \mathrm{O}_{\mathrm{w} \text {-ivc }}$ between 4 and $3.5 \mathrm{ka}$ BP but no temperature change is apparent for this interval.

Based on the records presented here, the Holocene can be divided into four sections: the early Holocene (11-8.2 ka BP) is characterized by a thermal difference between surface and subsurface waters. Together with the quite similar values in the $\delta^{18} \mathrm{O}_{\mathrm{w} \text {-ivc }}$ records, this points toward a temperaturedriven stratification during a period when the AF was south of its modern position. In the early mid-Holocene (8$6 \mathrm{ka} \mathrm{BP})$ the thermal difference between surface and subsurface waters decreased while the difference in $\delta^{18} \mathrm{O}_{\mathrm{w} \text {-ivc }}$ remained small, but both records shift to slightly higher values. This phase can be interpreted as an intermediate phase with a weak thermal stratification but increasing salinities that are accompanied by a northward movement of the AF, reaching its northernmost position. In the late mid-Holocene (6$4 \mathrm{ka} \mathrm{BP})$ the $\mathrm{AF}$ remained at the northernmost position, while evolving differences between surface and subsurface $T$ and $S$ indicate a stabilization of the thermohaline stratification. The late Holocene (4-0 ka BP) differs from the previous phase mainly in the position of the STG. The latter is replaced to a more southern position that is also observed under modern conditions.

\subsection{Transport between tropical and subpolar North Atlantic}

In order to investigate how changes in the mixed layer at our subtropical coring site can be related to changes in surface and subsurface warm water transport between the subtropical and subpolar North Atlantic, we compare our records with ODP 1058 and MD99-2203 records from the western subtropics (Bahr et al., 2013; Cléroux et al., 2012) and RAPID 12-1 from the subpolar North Atlantic (NA; Thornalley et 


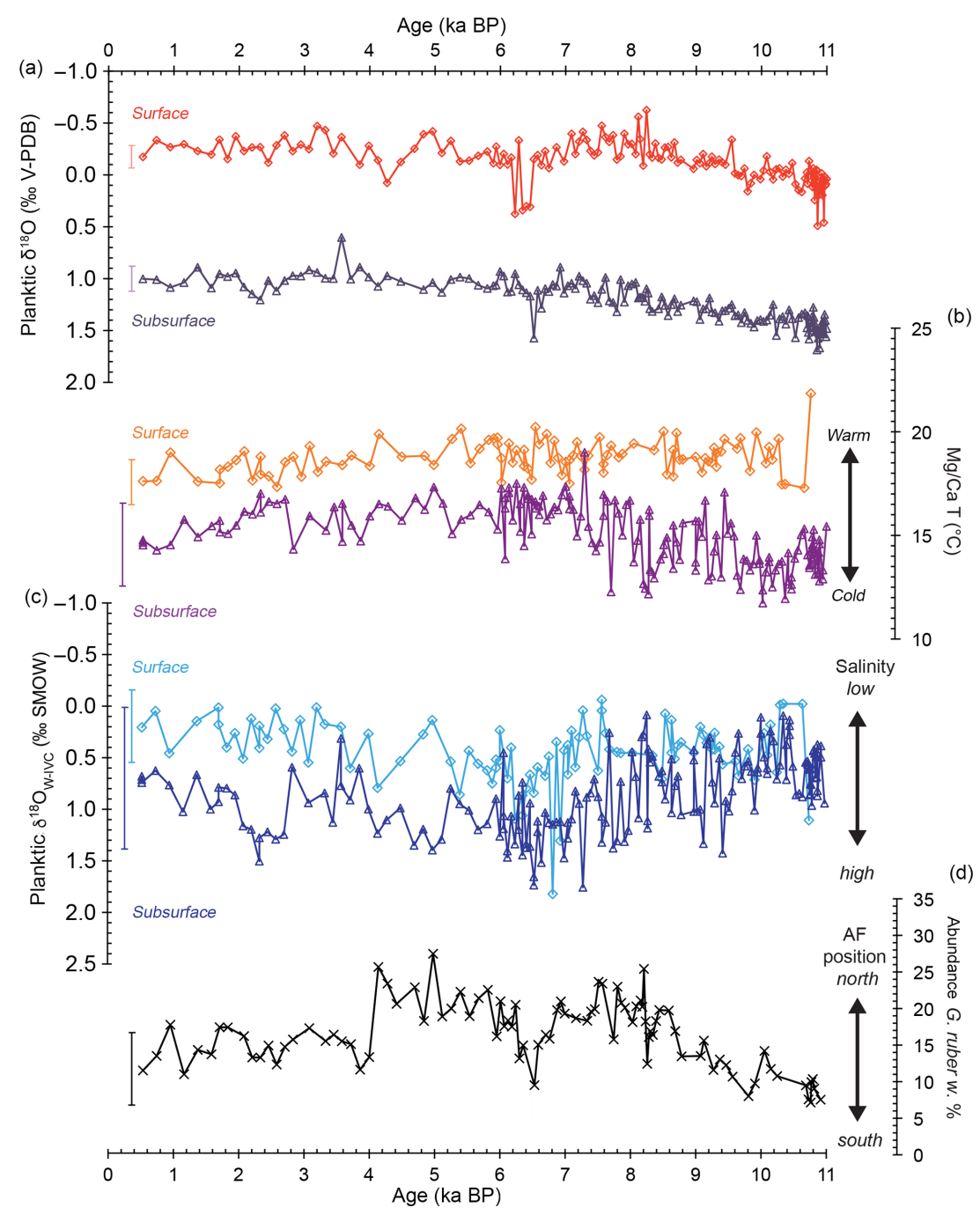

Figure 2. Results obtained from core GEOFAR KF16: (a) $\delta^{18}$ O records from surface- (G. ruber w.) (red diamonds; Schwab et al., 2012) and subsurface-dwelling planktonic foraminifera (G. truncatulinoides) (dark blue triangles; Repschläger et al., 2015), (b) Mg / Ca SST records from surface (G. ruber w.) (orange diamonds) and subsurface (G. truncatulinoides) (violet triangles), (c) $\delta^{18} \mathrm{O}_{\mathrm{w}-i v c}$ records from surface(G. ruber w.) (light blue diamonds) and subsurface (G. truncatulinoides)-dwelling planktonic foraminifera (blue triangles), (d) $G$. ruber w. abundance (Weinelt et al., 2015) as indicator for the AF position (black crosses). Grey bars indicate the $2 \sigma$ SD for all records.

al., 2009). To infer any connection to north-western SPG recirculation, our new datasets are also compared to temperature reconstructions from HU-90-13-13 (P-013) and HU-91045-094 (P094) from the Greenland Rise and Orphan Knoll (Solignac et al., 2004).

In general, SST estimates from the western subtropical, subtropical (Azores), and subpolar sites (Fig. 3) fluctuate by $2{ }^{\circ} \mathrm{C}$ around rather stable mean values of 27,18 , and $10^{\circ} \mathrm{C}$, respectively. The $\delta^{18} \mathrm{O}_{\mathrm{w} \text {-ivc }}$ records fluctuate by $\pm 0.4 \%$ around values of $1.2,0.9$, and $0 \%$. These fluctuations are within the errors of $\mathrm{Mg} / \mathrm{Ca}$ temperature estimation and seawater $\delta^{18} \mathrm{O}$ determinations. Assuming that the surface water properties at the three sites are mainly driven by changes in the surface water transport, we conclude that the mean northward surface water transport remained stable over the Holocene, which is associated with shifts in the AF latitudinal position.

Thus, any larger variability in North Atlantic inter-gyre heat and salt exchange must originate from changes in the subsurface transport. The subsurface signal from the tropical site is rather constant during the entire Holocene, with average tropical $T_{\text {sub }}$ fluctuating by $\pm 3{ }^{\circ} \mathrm{C}$ around a mean of $17.5^{\circ} \mathrm{C}$ and $\delta^{18} \mathrm{O}_{\mathrm{w} \text {-ivc }}$ varying by $0.5 \%$ around a mean of $1.2 \%$, and with no apparent long-term trends. In contrast, distinct temporal differences are observed in the subsurface records at the subtropical and subpolar sites (Fig. 3b).

From 11 to $8 \mathrm{kaBP}$, coincident with a southern position of the AF, subtropical subsurface records are similar to subpolar values, with low $T_{\text {sub }}$ of 12 and $10^{\circ} \mathrm{C}$ and low subsurface $\delta^{18} \mathrm{O}_{\mathrm{w} \text {-ivc }}$ of about $0.5 \%$. The surface water records sug- 

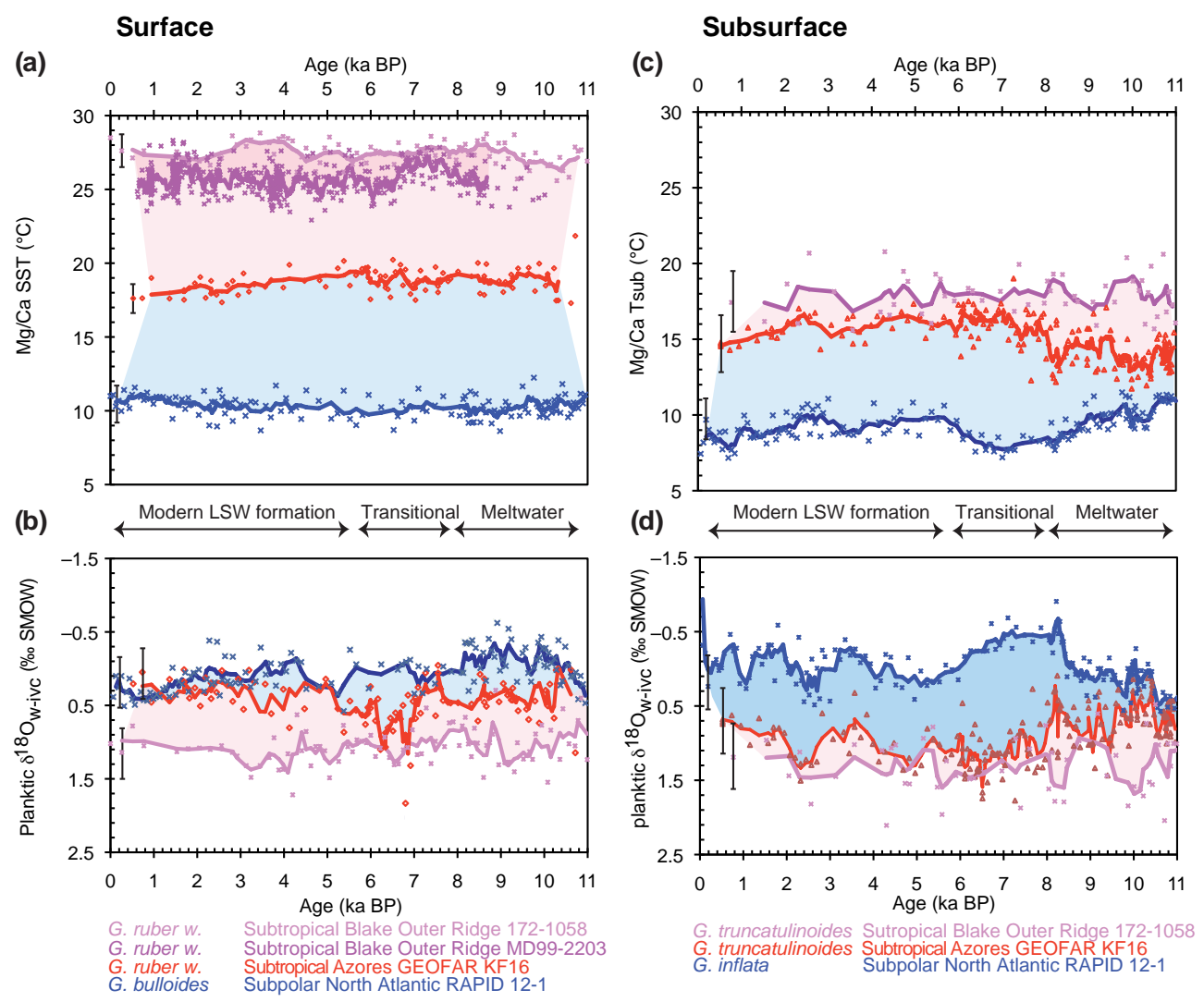

Figure 3. Surface and subsurface temperature and salinity reconstructions from the tropical to subpolar North Atlantic. Left panels show a comparison between (a) surface temperatures and (b) $\delta^{18} \mathrm{O}_{\mathrm{w}-\mathrm{ivc}}$ records from the tropical (pink) (Bahr et al., 2013), subtropical (red), and subpolar (blue) (Thornalley et al., 2009) North Atlantic. Right panels show a comparison between (c) subsurface temperatures and (d) $\delta^{18} \mathrm{O}_{\mathrm{w} \text {-ivc }}$ records from the tropical (pink) (Bahr et al., 2013), subtropical (red), and subpolar (blue) (Thornalley et al., 2009) North Atlantic. Grey bars indicate the SD for all records.

gest active northward water transport, similar to the state described at the transition between the Allerød and the Younger Dryas (Repschläger et al., 2015). The low subsurface $T$ and $\delta^{18} \mathrm{O}_{\mathrm{w} \text {-ivc }}$ during the early Holocene can be explained with an intrusion of transitional Eastern North Atlantic Water (ENAW) reaching the Azores site (Fig. 5a). This intrusion is probably related to the influence of meltwater from the Laurentide Ice Sheet, which is also inferred from a freshening in the subpolar North Atlantic (Came et al., 2007; Farmer et al., 2011; Thornalley et al., 2009), although the $\delta^{18} \mathrm{O}_{\mathrm{w} \text {-ivc }}$ records need to be confirmed by independent proxies.

During the mid-Holocene transitional phase (8-6 ka BP), subtropical and subpolar subsurface records diverge. The subtropical $T_{\text {sub }}$ and subsurface $\delta^{18} \mathrm{O}_{\mathrm{w} \text {-ivc }}$ values start to converge towards those from the subtropical Blake Outer Ridge record after $8.2 \mathrm{ka} \mathrm{BP}$, while the subpolar $T_{\text {sub }}$ record remains in the early Holocene mode and the $\delta^{18} \mathrm{O}_{\mathrm{w} \text {-ivc }}$ values imply further freshening. This state coincides with a northward migration of the AF. Warm subsurface waters reached the Azores coring site but were not transported further northward yet (Fig. 5b).
At $7 \mathrm{ka} \mathrm{BP}$ subtropical subsurface records from the Azores (GEOFAR KF16) reach values similar to those of the western subtropical record from the Blake Outer Ridge (ODP1058). The subpolar records (RAPID 12-1) follow the changes in the subtropical Azores records with a time lag of at least 1000 years, starting to converge towards the subtropical records at $7 \mathrm{kaBP}$. This indicates the onset of modern transport of warm subsurface waters from the subtropics into the subpolar region (Fig. 5c). At the same time, LSW formation started with a prominent salinity increase. At the same time, increasing NAC water influence in the Labrador Sea (Perner et al., 2013) and decreasing warm water transport within the NAC into the Nordic seas (Solignac et al., 2004; Staines-Uréas et al., 2013) occurred in surface waters south of Greenland (Fig. 4), followed by increasing salinities at Orphan Knoll (Fig. 4) (Solignac et al., 2004). These changes are potentially accompanied by a divergence of the warm water transport into the Irminger Basin and Labrador Sea at subsurface. To investigate this transport route, further highresolution SST and $T_{\text {sub }}$ reconstructions from the subpolar gyre would be needed. 
(a)

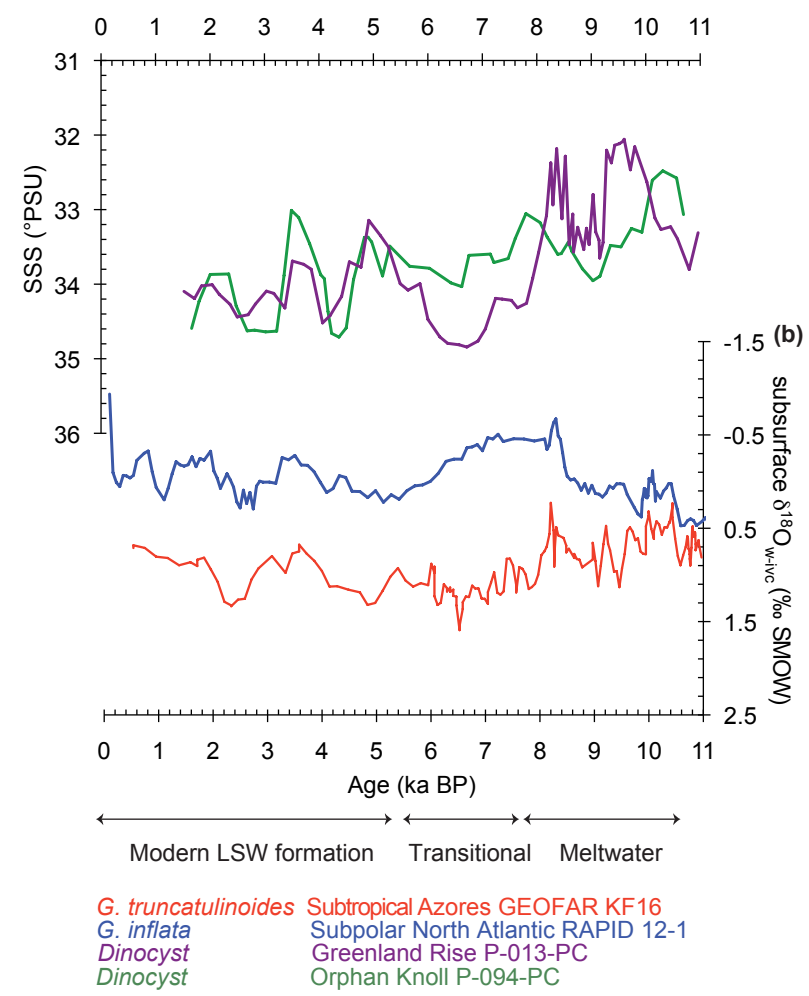

Figure 4. Comparison between (a) SSS reconstructions (summer season salinity estimates) based on dinoflagellate cyst assemblages from the northern and southern entrances of the Labrador Sea (Solignac et al., 2004) and (b) subsurface salinity reconstructions from subtropical (red) to subpolar (blue) North Atlantic $\delta^{18} \mathrm{O}_{\text {w-ivc }}$ records (Thornalley et al., 2009).

In the late Holocene after $6 \mathrm{kaBP}$, the western subtropical, subtropical (Azores), and subpolar records reveal parallel patterns with millennial-scale fluctuations in temperature and salinity that are anticorrelated with records from the Labrador Sea, as already described by Thornalley et al. (2009) and Cléroux et al. (2012). With this circulation mode, short-term variability, including antiphasing, between the SPG and STG temperature and salinity records is observed. Our data are thus in harmony with earlier suggestions of antiphasing between gyre properties for the late Holocene records (Cléroux et al., 2012; Thornalley et al., 2009). This variability may imply that short-term freshening events in the Labrador Sea can be balanced by increased warm and saline water transport between the SPG and the STG, stabilizing the AMOC. However, our data now prominently indicate that the major pathway in this stabilization mechanism at the millennial timescale must be the subsurface warm water route in the North Atlantic.
Surprisingly, no changes in the long-term trend of the late Holocene are observed after $4 \mathrm{ka} \mathrm{BP}$ when changes in the $G$. ruber $\mathrm{w}$. abundance indicate a southward movement of the AF position (Repschläger et al., 2015), which can be associated with a global southward shift of the wind systems (Wanner, 2008).

\subsection{Driving factors for subsurface transport changes and AF position}

In light of observed and anticipated anthropogenic climate change, it is important to understand the underlying mechanism of Holocene climate variability. In addition to the forcing by increases in atmospheric $\mathrm{CO}_{2}$, four driving factors may be of importance for the observed Holocene changes in the Azores region: (1) changes in AC transport strength and position due to changes in Mediterranean Outflow Water (MOW) strength, (2) changes in the atmospheric circulation related to the northern hemispheric summer insolation (Renssen, 2005) and changes in North Atlantic Oscillation (NAO) patterns (e.g., Olsen et al., 2012; Wassenburg et al., 2016), (3) changes in meltwater forcing over the North Atlantic region due to melting of continental ice sheets (Mayewski et al., 2004), and (4) changes in solar activity (Bond et al., 2001). The latter will not be discussed due to the relatively low resolution of the late Holocene record, which hampers time series analyses. In the following we will discuss which of factors one to three can be identified as the main cause for the variability in subsurface transport.

1. According to modeling studies (Volkov and Fu, 2010), the strength of the $\mathrm{AC}$ is closely linked to the strength of MOW. Nevertheless, little is known about its influence on the $\mathrm{AC}$ position and the question arises whether observed changes in $\mathrm{AC}$ position can be related to changes in MOW strength. Reconstructions of MOW strength based on contourite grain size data from the Gulf of Cádiz indicate that MOW was sluggish during the early Holocene and strengthened after $8 \mathrm{ka}$ BP. During the last 2 millennia, MOW strength decreased again (Rogerson et al., 2012; Toucanne et al., 2007). Thus, the timing of the early Holocene MOW strengthening roughly coincides with a northward movement of the AF-AC and a strengthening of the subsurface warm water transport. The late Holocene southward movement of the AF-AC, reconstructed from $G$. ruber w. abundance at $4 \mathrm{kaBP}$, precedes the MOW weakening by about $2 \mathrm{ky} \mathrm{BP}$ and does not exactly match the AF-AC signal. Though a connection between more intense MOW and increasing subsurface warm water transport in the AC-AF is likely, a connection between $\mathrm{AC}$ position and MOW strength cannot be definitely proven. MOW outflow is mainly driven by the density gradient between the Mediterranean Sea and the Strait of Gibraltar (Ivanovic et al., 2014 , and citations therein). The latter is probably gov- 
(a) Early Holocene

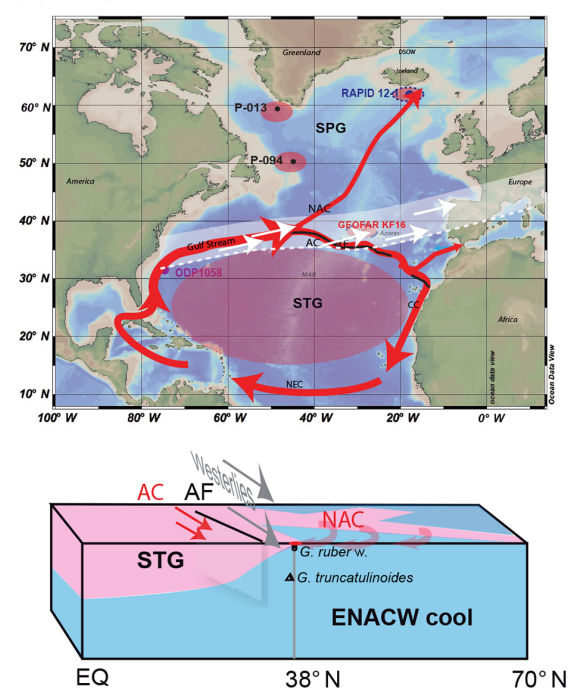

(b) Mid-Holocene
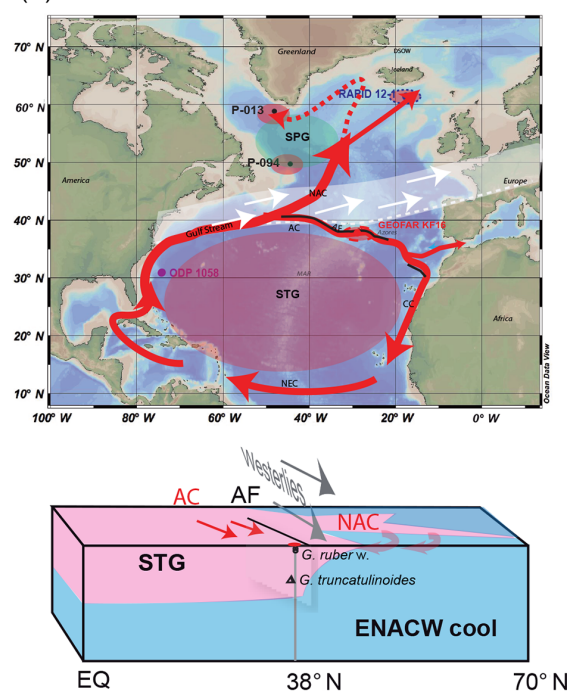

(c) Late Holocene
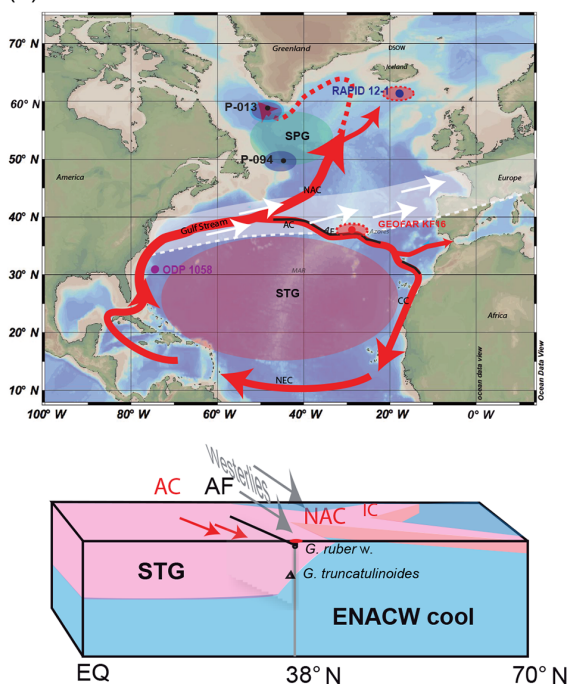

Figure 5. Conceptual model showing the three different states of subsurface transport: (a) early Holocene meltwater phase, (b) mid-Holocene transitional phase, and (c) late Holocene modern phase. Abbreviations are AC, Azores Current; AF, Azores Front; ENACW, Eastern North Atlantic Central Water; NAC, North Atlantic Current; STG, subtropical gyre; and SPG, subpolar gyre.

erned by the strength of the thermohaline circulation in the North Atlantic as well as by atmospheric circulation changes (Bozec et al., 2011; Voelker et al., 2006). If both are also closely related to the position and strength of the $\mathrm{AC}-\mathrm{AF}$ this suggests that atmospheric and thermohaline circulation act as a common driver for the early to mid-Holocene changes in the $\mathrm{AF}-\mathrm{AC}$ position and MOW strength rather than MOW strength being the main driver in the position of the $\mathrm{AC}-\mathrm{AF}$.

2. Paleoceanographic reconstructions and modeling studies suggest that the early to mid-Holocene northern hemispheric maximum in summer insolation led to a weakening of the pressure gradient between the tropical and subpolar North Atlantic. This relaxation of pressure probably led to a northward movement of the westerly wind belt (Renssen, 2005) that controls the position of the AC-AF. The exact position of the westerly wind belt is still controversially discussed, including dynamics of the NAO. The NAO is the most prominent modern atmospheric circulation variability in the North Atlantic region. It is defined by the pressure difference between the Icelandic low-pressure zone and the Azores highpressure cell. $\mathrm{NAO}^{+/-}$phases are characterized by a strong or weak pressure gradient between Iceland and the Azores and strengthening or weakening of the westerlies (Hurrell and Deser, 2009; Hurrell et al., 2001). As the westerlies strength is assumed to have a major influence on the AF position, NAO changes might 
be a driver of its variable position. Furthermore, NAO changes are also assumed to influence the strength of the STG-SPG dynamics, e.g., in the way that heat advection to the Labrador Sea may be increased during weak $\mathrm{NAO}^{-}$years (Olsen et al., 2012).

The influence of the insolation-driven early Holocene thermal maximum on NAO has been controversially discussed, either leading to a more positive (Olsen et al., 2012; Wanner, 2008) or negative NAO mode (Morley et al., 2014). Modeling studies (Gladstone et al., 2005) could not confirm a mid-Holocene $\mathrm{NAO}^{+}$mode and a new speleothem dataset reconstructed multi-decadal $\mathrm{NAO}^{+/-}$oscillations that were active over the entire Holocene (Wassenburg et al., 2016). Such a short-term variability is not resolved in our records and cannot account for the long-term subsurface transport changes. Thus, NAO patterns seem to play a subordinate role for the variability observed in our records.

In addition to multi-decadal $\mathrm{NAO}^{+/-}$oscillations, Wassenburg et al. (2016) reconstructed early to midHolocene changes in the geometry of the Icelandic Low and Azores High pressure cells that were accompanied by a redirection of the westerlies to the southwesterly wind direction during the early Holocene (11-9 ka BP). These changes cannot be driven by insolation changes alone and seem to be strongly overprinted by the extent of the Laurentide Ice Sheet and meltwater surges, as shown in a modeling study using a fully coupled earth system model (Wassenburg et al., 2016).

A change in wind direction between 8 and $9 \mathrm{ka} \mathrm{BP}$ into a mid-Holocene mode with a northward movement of the westerlies is in agreement with our G. ruber w. data, which indicate a northward movement of the AF between 8 and $9 \mathrm{ka} \mathrm{BP}$. A southward movement of the AF is indicated in our G. ruber w. data and can be associated with strengthening of the westerly wind belt at about $4 \mathrm{ka} \mathrm{BP}$, the latter matching large-scale reorganization of the atmospheric circulation, including a southward shift in the westerly wind belt and in the Intertropical Convergence Zone (ITCZ) position (Wanner, 2008, and citations therein).

Despite the coincidence of frontal movements with Holocene changes in the northern hemispheric wind fields, inferred changes in the AF position do not coincide with the onset of the northward subsurface water transport. The onset of the subsurface transport and LSW formation lag behind the northward movement of the AF and reorganization of the atmospheric circulation by about $2 \mathrm{ky}$ and lead the southward movement of the AF at $4 \mathrm{ka} \mathrm{BP}$ by $2 \mathrm{ky}$. Thus, the onset of the subsurface transport seems to be decoupled from the strength of the atmospheric circulation.
3. Given the strong impact of the ice sheets and meltwater on the atmospheric circulation, as the main driver of the early to mid-Holocene changes (Wassenburg et al., 2016), we examine changes in meltwater and their timing more closely as a potential driver for changes in the subsurface transport.

The timing of the start of increased subsurface transport at about $7 \mathrm{kaBP}$ into the Labrador Sea coincides well with the termination of the global sea level rise at that time (Austermann et al., 2013; Wanner, 2008), the end of meltwater flow into the Labrador Sea (Jennings et al., 2015), and increasing transport of Atlantic water into the Labrador Sea (Perner et al., 2013). The onset of the northward subsurface warm water transport agrees with the stabilization of the North Atlantic deepwater circulation that previously was related to the onset of LSW formation (Hoogakker et al., 2011; Thornalley et al., 2013). Alternatively, as recently discussed (Blaschek et al., 2015), this stabilization may be mainly related to an increase in Nordic sea deepwater convection, though more studies are needed to confirm this theory.

\section{Conclusion}

In this study we show a stepwise evolution of the mixed layer temperature and salinity at the AF during the Holocene that is closely linked to a northward migration of the $\mathrm{AF}$ and related transport of warm water within the NAC system.

The mean surface warm water transport from the tropics into the subpolar North Atlantic remained relatively stable over the last $11 \mathrm{ky} \mathrm{BP}$. In contrast, subsurface transport into the North Atlantic evolved in three phases: an early Holocene meltwater phase (11-8 ka BP) with no subsurface transport, a mid-Holocene transitional phase (8-6 ka BP) with subsurface transport that reached the AF but not the subpolar NA and a late Holocene to modern phase (6-0 ka BP) with subsurface transport into the subpolar NA that coincides with the onset of LSW formation. Within these scenarios, changes in the AF position seem to be driven by changes in the atmospheric circulation and are decoupled from subsurface transport changes. The latter are mainly driven by the amount of meltwater in the subpolar North Atlantic and are probably more important for the AMOC evolution than changes in the atmospheric circulation. Multimillennial-scale variability in the subsurface transport between 10 and $6 \mathrm{kaBP}$ is in antiphase with Labrador Sea records as well as STG and SPG subsurface water properties, similar to previous studies postulating short-term antiphase inter-gyre dynamics as a potential stabilizing mechanism for the modern LSW formation. Accordingly, NA subsurface transport pathways appear to have had an important role in the mid- to late Holocene climate stabilization. However, this aspect needs to be investigated further in high latitudes in order to obtain a full understanding of underlying forcing mechanisms. 
Data availability. Data is available under doi:10.1594/PANGAEA.868108 (Repschläger, 2016).

\section{The Supplement related to this article is available online at doi:10.5194/cp-13-333-2017-supplement.}

Competing interests. The authors declare that they have no conflict of interest.

Acknowledgements. We acknowledge M. Regenberg and K. Bremer for laboratory assistance and M. Kienast for final proofreading. The presented data are obtained from core GEOFAR KF16, that was generously provided by Bernard Dennielou at IFREMER. The work presented here was supported by the European Science Foundation (ESF) within the EUROCORES Program EuroMARC through contract no. ERAS-CT-2003-980409 of the European Commission, DG Research, FPG. The German Science Foundation (DFG) also contributed financial support (WE 2679/6-1).

Edited by: A. Winguth

Reviewed by: two anonymous referees

\section{References}

Alves, M., Gaillard, F., Sparrow, M., Knoll, M., and Giraud, S.: Circulation patterns and transport of the Azores Front-Current system, Deep-Sea Res. Pt. II, 49, 3983-4002, 2002.

Andersen, C., Koç, N., and Moros, M.: A highly unstable Holocene climate in the subpolar North Atlantic: evidence from diatoms, Quaternary Sci. Rev., 23, 2155-2166, 2004.

Andrews, J. T. and Giraudeau, J.: Multi-proxy records showing significant Holocene environmental variability: the inner N. Iceland shelf (Húnaflói), Quaternary Sci. Rev., 22, 175-193, 2003.

Austermann, J., Mitrovica, J. X., Latychev, K., and Milne, G. A.: Barbados-based estimate of ice volume at Last Glacial Maximum affected by subducted plate, Nat. Geosci., 6, 553-557, 2013.

Bahr, A., Nürnberg, D., Karas, C., and Grützner, J.: Millennial-scale versus long-term dynamics in the surface and subsurface of the western North Atlantic Subtropical Gyre during Marine Isotope Stage 5, Global Planet. Change, 111, 77-87, 2013.

Blaschek, M., Renssen, H., Kissel, C., and Thornalley, D.: Holocene North Atlantic Overturning in an atmosphere-ocean-sea ice model compared to proxy-based reconstructions, Paleoceanography, 30, 1503-1524, doi:10.1002/2015PA002828, 2015.

Bond, G., Kromer, B., Beer, J., Muscheler, R., Evans, M. N., Showers, W., Hoffmann, S., Lotti-Bond, R., Hajdas, I., and Bonani, G.: Persistent Solar Influence on North Atlantic Climate During the Holocene, Science, 294, 2130-2136, doi:10.1126/science.1065680, 2001.

Born, A. and Stocker, T. F.: Two Stable Equilibria of the Atlantic Subpolar Gyre, J. Phys. Oceanogr., 44, 246-264, 2014.

Bozec, A., Lozier, M. S., Chassignet, E. P., and Halliwell, G. R.: On the variability of the Mediterranean Outflow Water in the North
Atlantic from 1948 to 2006, J. Geophys. Res., 116, C09033, doi:10.1029/2011JC007191, 2011.

Brambilla, E. and Talley, L.: Surface drifter exchange between the North Atlantic subtropical and subpolar gyres, J. Geophys. Res., 111, C07026, doi:10.1029/2005jc003146, 2006.

Came, R. E., Oppo, D. W., and McManus, J. F.: Amplitude and timing of temperature and salinity variability in the subpolar North Atlantic over the past 10 k.y, Geology, 35, 315-318, 2007.

Campbell, I. D., Campbell, C., Apps, M. J., Rutter, N. W., and Bush, A. B. G.: Late Holocene $\sim 1500 \mathrm{yr}$ climatic periodicities and their implications, Geology, 26, 471-473, 1998.

Cléroux, C., Cortijo, E., Anand, P., Labeyrie, L., Bassinot, F., Caillon, N., and Duplessy, J.-C.: $\mathrm{Mg} / \mathrm{Ca}$ and $\mathrm{Sr} / \mathrm{Ca}$ ratios in planktonic foraminifera: Proxies for upper water column temperature reconstruction, Paleoceanography, 23, PA3214, doi:10.1029/2007PA001505, 2008.

Cléroux, C., Debret, M., Cortijo, E., Duplessy, J.-C., Dewilde, F., Reijmer, J., and Massei, N.: High-resolution sea surface reconstructions off Cape Hatteras over the last $10 \mathrm{ka}$, Paleoceanography, 27, PA1205, doi:10.1029/2011pa002184, 2012.

Farmer, E. J., Chapman, M. R., and Andrews, J. E.: Holocene temperature evolution of the subpolar North Atlantic recorded in the $\mathrm{Mg} / \mathrm{Ca}$ ratios of surface and thermocline dwelling planktonic foraminifers, Global Planet. Change, 79, 234-243, 2011.

Foukal, N. P. and Lozier, M. S.: No inter-gyre pathway for seasurface temperature anomalies in the North Atlantic, Nat. Commun., 7, doi:10.1038/ncomms11333, 2016.

Giraudeau, J., Grelaud, M., Solignac, S., Andrews, J. T., Moros, M., and Jansen, E.: Millennial-scale variability in Atlantic water advection to the Nordic Seas derived from Holocene coccolith concentration records, Quaternary Sci. Rev., 29, 1276-1287, 2010.

Gladstone, R. M., Ross, I., Valdes, P. J., Abe-Ouchi, A., Braconnot, P., Brewer, S., Kageyama, M., Kitoh, A., Legrande, A., Marti, O., Ohgaito, R., Otto-Bliesner, B., Peltier, W. R., and Vettoretti, G.: Mid-Holocene NAO: A PMIP2 model intercomparison, Geophys. Res. Lett., 32, L16707, doi:10.1029/2005g1023596, 2005.

Gould, W. J.: Physical oceanography of the Azores front, Prog. Oceanogr., 14, 167-190, 1985.

Hoogakker, B. A. A., Chapman, M. R., McCave, I. N., Hillaire-Marcel, C., Ellison, C. R. W., Hall, I. R., and Telford, R. J.: Dynamics of North Atlantic Deep Water masses during the Holocene, Paleoceanography, 26, PA4214, doi:10.1029/2011PA002155, 2011.

Hurrell, J. W. and Deser, C.: North Atlantic climate variability: The role of the North Atlantic Oscillation, J. Marine Syst., 78, 28-41, 2009.

Hurrell, J. W., Kushnir, Y., and Visbeck, M.: The North Atlantic Oscillation, Science, 291, 603-605, 2001.

Ivanovic, R. F., Valdes, P. J., Gregoire, L., Flecker, R., and Gutjahr, M.: Sensitivity of modern climate to the presence, strength and salinity of Mediterranean-Atlantic exchange in a global general circulation model, Clim. Dynam., 42, 859-877, 2014.

Jennings, A., Andrews, J., Pearce, C., Wilson, L., and Ólfasdótttir, S.: Detrital carbonate peaks on the Labrador shelf, a 13-7 ka template for freshwater forcing from the Hudson Strait outlet of the Laurentide Ice Sheet into the subpolar gyre, Quaternary Sci. Rev., 107, 62-80, 2015. 
Kissel, C., Van Toer, A., Laj, C., Cortijo, E., and Michel, E.: Variations in the strength of the North Atlantic bottom water during Holocene, Earth Planet. Sc. Lett., 369-370, 248-259, 2013.

Leduc, G., Schneider, R., Kim, J. H., and Lohmann, G.: Holocene and Eemian sea surface temperature trends as revealed by alkenone and $\mathrm{Mg}$ / Ca paleothermometry, Quaternary Sci. Rev., 29, 989-1004, 2010.

Lherminier, P., Mercier, H., Huck, T., Gourcuff, C., Perez, F. F., Morin, P., Sarafanov, A., and Falina, A.: The Atlantic Meridional Overturning Circulation and the subpolar gyre observed at the A25-OVIDE section in June 2002 and 2004, Deep-Sea Res. Pt. I, 57, 1374-1391, 2010.

Lozier, M. S.: Overturning in the North Atlantic, Annu. Rev. Mar. Sci., 4, 291-315, 2012.

Martin, P. A. and Lea, D. W.: A simple evaluation of cleaning procedures on fossil benthic foraminiferal $\mathrm{Mg} / \mathrm{Ca}$, Geochem. Geophy. Geosy., 3, 8401, doi:10.1029/2001GC000280, 2002.

Mayewski, P. A., Rohling, E. E., Curt Stager, J., Karlén, W., Maasch, K. A., David Meeker, L., Meyerson, E. A., Gasse, F., van Kreveld, S., Holmgren, K., Lee-Thorp, J., Rosqvist, G., Rack, F., Staubwasser, M., Schneider, R. R., and Steig, E. J.: Holocene climate variability, Quaternary Res., 62, 243-255, 2004.

Mertens, C., Rhein, M., Walter, M., Böning, C. W., Behrens, E., Kieke, D., Steinfeldt, R., and Stöber, U.: Circulation and transports in the Newfoundland Basin, western subpolar North Atlantic, J. Geophys. Res.-Oceans, 119, 7772-7793, 2014.

Morley, A., Rosenthal, Y., and deMenocal, P.: Ocean-atmosphere climate shift during the mid-to-late Holocene transition, Earth Planet. Sc. Lett., 388, 18-26, 2014.

Moros, M., Emeis, K., Risebrobakken, B., Snowball, I., Kuijpers, A., McManus, J., and Jansen, E.: Sea surface temperatures and ice rafting in the Holocene North Atlantic: climate influences on northern Europe and Greenland, Quaternary Sci. Rev., 23, 21132126, 2004.

Moros, M., Andrews, J. T., Eberl, D. D., and Jansen, E.: Holocene history of drift ice in the northern North Atlantic: Evidence for different spatial and temporal modes, Paleoceanography, 21, PA2017, doi:10.1029/2005pa001214, 2006.

Olsen, J., Anderson, N. J., and Knudsen, M. F.: Variability of the North Atlantic Oscillation over the past 5,200 years, Nat. Geosci., 5, 808-812, 2012.

Ottens, J. J.: Planktic foraminifera as North Atlantic water mass indicators, Oceanol. Acta, 14, 123-140, 1991.

Ottens, J. J. and Nederbragt, A. J.: Planktic foraminiferal diversity as indicator of ocean environments, Mar. Micropaleontol., 19, 13-28, 1992.

Perner, K., Moros, M., Jennings, A., Lloyd, J., and Knudsen, K.: Holocene palaeoceanographic evolution off West Greenland, Holocene, 23, 374-387, 2013.

Renssen, H.: Simulating the Holocene climate evolution at northern high latitudes using a coupled atmosphere-sea ice-oceanvegetation model, Clim. Dynam., 24, 23-43, 2005.

Repschläger, J.: $\mathrm{Mg}$ / Ca ratio, oxygen isotopes and surface temperatures derived from $G$. ruber and G. truncatulinoides in core GEOFAR KF16, doi:10.1594/PANGAEA.868108, 2016.

Repschläger, J., Weinelt, M., Kinkel, H., Andersen, N., GarbeSchönberg, D., and Schwab, C.: Response of the subtropical North Atlantic surface hydrography on deglacial and
Holocene AMOC changes, Paleoceanography, 30, 456-476, doi:10.1002/2014pa002637, 2015.

Roessler, A., Rhein, M., Kieke, D., and Mertens, C.: Long-term observations of North Atlantic Current transport at the gateway between western and eastern Atlantic, J. Geophys. Res.-Oceans, 120, 4003-4027, 2015.

Rogerson, M., Rohling, E. J., Bigg, G. R., and Ramirez, J.: Paleoceanography of the Atlantic-Mediterranean exchange: Overview and first quantitative assessment of climatic forcing, Rev. Geophys., 50, RG2003, doi:10.1029/2011RG000376, 2012.

Sarafanov, A., Falina, A., Mercier, H., Sokov, A., Lherminier, P., Gourcuff, C., Gladyshev, S., Gaillard, F., and Daniault, N.: Mean full-depth summer circulation and transports at the northern periphery of the Atlantic Ocean in the 2000s, J. Geophys. Res., 117, C01014, doi:10.1029/2011jc007572, 2012.

Schiebel, R., Waniek, J., Zeltner, A., and Alves, M.: Impact of the Azores Front on the distribution of planktic foraminifers, shelled gastropods, and coccolithophorids, Deep-Sea Res. Pt. II, 49, 4035-4050, 2002.

Schlitzer, R.: Ocean Data View, available at: http://odv.awi.de (last access: 7 April 2017), 2012.

Schott, F. A., Zantopp, R., Stramma, L., Dengler, M., Fischer, J. R., and Wibaux, M.: Circulation and Deep-Water Export at the Western Exit of the Subpolar North Atlantic, J. Phys. Oceanogr., 34, 817-843, 2004.

Schulz, M., Paul, A., and Timmermann, A.: Glacial-interglacial contrast in climate variability at centennial-to-millennial timescales: observations and conceptual model, Quaternary Sci. Rev., 23, 2219-2230, 2004.

Schwab, C., Kinkel, H., Weinelt, M., and Repschläger, J.: Coccolithophore paleoproductivity and ecology response to deglacial and Holocene changes in the Azores Current System, Paleoceanography, 27, PA3210, doi:10.1029/2012pa002281, 2012.

Shackleton, N. J.: Attainment of isotopic equilibrium ocean water and the benthonic foraminifera genus Uvigerina: Isotopic changes in the ocean during the last glacial, Cent. Natl. Rech. Sci. Colloq. Int., 219, 203-209, 1974.

Solignac, S., de Vernal, A., and Hillaire-Marcel, C.: Holocene seasurface conditions in the North Atlantic - contrasted trends and regimes in the western and eastern sectors (Labrador Sea vs. Iceland Basin), Quaternary Sci. Rev., 23, 319-334, 2004.

Spall, M. and Pickart, A.: Wind-driven recirculations and exchange in the Labrador and Irminger Seas, J. Phys. Oceanogr., 33, 1829-1845, doi:10.1175/15200485(2003)033<1829:WRAEIT>2.0.CO;2, 2003.

Staines-Uréas, F., Kuijpers, A., and Korte, C.: Evolution of subpolar North Atlantic surface circulation since the early Holocene inferred from planktic foraminifera faunal and stable isotope records, Quaternary Sci. Rev., 76, 66-81, 2013.

Storz, D., Schulz, H., Waniek, J. J., Schulz-Bull, D. E., and Kufçera, M.: Seasonal and interannual variability of the planktic foraminiferal flux in the vicinity of the Azores Current, Deep-Sea Res. Pt. I, 56, 107-124, 2009.

Thornalley, D. J. R., Elderfield, H., and McCave, I. N.: Holocene oscillations in temperature and salinity of the surface subpolar North Atlantic, Nature, 457, 711-714, 2009.

Thornalley, D. J. R., Blaschek, M., Davies, F. J., Praetorius, S., Oppo, D. W., McManus, J. F., Hall, I. R., Kleiven, H., Renssen, H., and McCave, I. N.: Long-term variations in Iceland-Scotland 
overflow strength during the Holocene, Clim. Past, 9, 20732084, doi:10.5194/cp-9-2073-2013, 2013.

Toucanne, S., Mulder, T., Schönfeld, J., Hanquiez, V., Gonthier, E., Duprat, J., Cremer, M., and Zaragosi, S.: Contourites of the Gulf of Cadiz: A high-resolution record of the paleocirculation of the Mediterranean outflow water during the last 50,000 years, Palaeogeogr. Palaeocl., 246, 354-366, 2007.

Våge, K., Pickart, R. S., Sarafanov, A., Knutsen, ò., Mercier, H., Lherminier, P., van Aken, H. M., Meincke, J., Quadfasel, D., and Bacon, S.: The Irminger Gyre: Circulation, convection, and interannual variability, Deep-Sea Res. Pt. I, 58, 590-614, 2011.

Viau, A. E., Gajewski, K., Sawada, M. C., and Fines, P.: Millennial-scale temperature variations in North America during the Holocene, J. Geophys. Res.-Atmos., 111, D09102, doi:10.1029/2005JD006031, 2006.

Voelker, A. H. L., Lebreiro, S. M., Schönfeld, J., Cacho, I., Erlenkeuser, H., and Abrantes, F.: Mediterranean outflow strengthening during northern hemisphere coolings: A salt source for the glacial Atlantic?, Earth Planet. Sc. Lett., 245, 39-55, 2006.

Volkov, D. L. and Fu, L.-L.: On the Reasons for the Formation and Variability of the Azores Current, J. Phys. Oceanogr., 40, 21972220, 2010.

Volkov, D. L. and Fu, L.-L.: Interannual variability of the Azores Current strength and eddy energy in relation to atmospheric forcing, J. Geophys. Res., 116, C11011, doi:10.1029/2011jc007271, 2011.
Walker, M. J. C., Berkelhammer, M., Björck, S., Cwynar, L. C., Fisher, D. A., Long, A. J., Lowe, J. J., Newnham, R. M., Rasmussen, S. O., and Weiss, H.: Formal subdivision of the Holocene Series/Epoch: a Discussion Paper by a Working Group of INTIMATE (Integration of ice-core, marine and terrestrial records) and the Subcommission on Quaternary Stratigraphy (International Commission on Stratigraphy), J. Quaternary Sci., 27, 649-659, 2012.

Wanner, H.: Mid- to late Holocene climate change: An overview, Quaternary Sci. Rev., 27, 1791-1828, 2008.

Wassenburg, J. A., Dietrich, S., Fietzke, J., Fohlmeister, J., Jochum, K. P., Scholz, D., Richter, D. K., Sabaoui, A., Spotl, C., Lohmann, G., Andreae, M. O., and Immenhauser, A.: Reorganization of the North Atlantic Oscillation during early Holocene deglaciation, Nat. Geosci., 9, 602-605, 2016.

Weinelt, M., Schwab, C., Kneisel, J., and Hinz, M.: Climate and societal change in the western Mediterranean area around $4.2 \mathrm{ka}$ BP, in: $2200 \mathrm{BC}$ - Ein Klimasturz als Ursache für den Zerfall der Alten Welt? (2200 BC - A climatic breakdown as a cause for the collapse of the old world?), 7. Mitteldeutscher Archäologentag, 17-19 October 2013, Halle (Saale), edited by: Meller, H., Arz, H. W., Jung, R., and Risch, R., Tagungen des Landesmuseums für Vorgeschichte Halle 12, Halle [Saale], 2015. 